\title{
URBAN WASTEWATER TREATMENT THROUGH A SYSTEM OF GREEN FILTERS IN THE MONTAÑITA COMMUNE, SANTA ELENA, ECUADOR
}

\author{
FERNANDO MORANTE CARBALLO ${ }^{1,2,3}$, LESLIE MARCATOMA BRITO ${ }^{1,3}$, PAÚL CARRIÓN MERO ${ }^{1,4}$, \\ MARIBEL AGUILAR AGUILAR ${ }^{5} \&$ JUAN TUMBACO RAMÍREZ ${ }^{5}$ \\ ${ }^{1}$ Centro de Investigaciones y Proyectos Aplicados a las Ciencias de la Tierra, \\ ESPOL Polytechnic University, Escuela Superior Politécnica del Litoral, Ecuador \\ ${ }^{2}$ Geo-recursos GIGA, ESPOL Polytechnic University, Escuela Superior Politécnica del Litoral, Ecuador \\ ${ }^{3}$ Facultad de Ciencias Naturales y Matemáticas, ESPOL Polytechnic University, \\ Escuela Superior Politécnica del Litoral, Ecuador \\ ${ }^{4}$ Facultad de Ingeniería Ciencias de la Tierra, ESPOL Polytechnic University, \\ Escuela Superior Politécnica del Litoral, Ecuador \\ ${ }^{5}$ Junta Administradora de Agua Potable Regional Manglaralto (JAAPMAN), Ecuador
}

\begin{abstract}
In land application, soil is used as a natural filter to remove pollution from urban wastewater. The soil also has two other functions, first of all it's the receiving medium of wastewater and secondly it works as an active agent because physical, chemical and biological reactions are made in the soil-water-crops ecosystem. This non-conventional treatment is effective at removing pollutants such as suspended solids, organic matter, nitrogen, phosphorus and microorganism form effluent streams. The aim of this study is to design a pilot plant using soil as a natural filter for the treatment of wastewater discharge from oxidation ponds located in the Montañita commune through selecting and evaluating the site, calculating the design hydraulic load and the area necessary for system application. To take samples at different depths, a lysimeter was constructed that allowed to take samples at 30,60 and $90 \mathrm{~cm}$ of depth. The variables that were measured in the treated water were total coliforms and $\mathrm{BOD}_{5}$. These variables were related to the values calculated for the discharge of the oxidation ponds and the percentage of removal for each sample taken. As a result, high removal percentages were obtained at $90 \mathrm{~cm}$ depth with respect to the level of application of the residual water. Percentages of up to $79 \%$ for total coliforms and $80 \%$ for $\mathrm{BOD}_{5}$ were obtained. These results are consistent with the limits established in the UTSLME (Unified Text of the Secondary Legislation of the Ministry of Environment). Finally, it could be concluded that soil in the area where the land application pilot plant was developed is suitable for efficient removal of the contaminants present in the discharge of oxidation ponds. This system contributed to the reduction of the pollution generated; in addition, the treatment of wastewater helps reforestation of this arid zone.
\end{abstract}

Keywords: green filter, Manglaralto commune, urban wastewater, $\mathrm{BOD}_{5}$, lysimeter.

\section{INTRODUCTION}

There are different wastewater treatment systems, including a non-conventional method called green filters, which makes use of the soil. Soil is a complex, reactive, fertile, permeable medium and is the first water filter [1], these provide two environmental services: (i) as a buffer, to store water, carbon and nutrients as well as to host flora and fauna; and (ii) in filtration, allowing the passage of water, carbon and the ability to convert chemical compounds [2].

As filtering agent, the system is constituted by an area of land where plant species are established, which is irrigated by wastewater through an irrigation system, developing physical, chemical and biological processes that develop in the soil-water-cultivation ecosystem, in order to eliminate almost all water pollutants, including suspended solids, nitrogen and phosphorus, reaching a purification of up to $98 \%$ in the first centimeters of the soil [3]. 
This type of water is used for irrigation since the last century in a controlled manner in several parts of Europe, Australia, India and the USA, when the "fields of application" were created, as Braatz and Kandiah point out in their article [4], while some treatment plants evacuate part of the effluent to irrigate golf courses and arid or semi-arid areas in those that exist shortage of water [5]. This has been generalized, for example, in China, more than 1.33 million hectares of farmland have been irrigated [6]. Part of this goes to rural areas where $67 \%$ of people live in this territory, so wastewater treatment systems have naturally increased, such as conventional land and septic ditch systems of land [7]. In California, USA, wastewater is largely applied to agricultural irrigation, these treated effluents are used in various food crops such as apples, broccoli, lettuce and cotton [8]. Arboreal species such as cascol (Enterolobium cyclocarpum) or guayacán (Guaiacum officinale) have a percentage higher than $90 \%$ of survival to irrigation with this type of water [6].

The criterion of water quality, generally applied in agricultural reuse, is mainly based on microbiological aspects due to the presence of pathogens [9], total dissolved solids and saline aspects [10]. Levine and Assano present more specific parameters for water re-use [11]. Based on this, the quality of the effluent is analyzed by means of total coliforms, which are the bacteria that produce fluorescent colonies when they are under ultraviolet light exposure [12], and the biological oxygen demand $\left(\mathrm{BOD}_{5}\right)$.

The parish of Manglaralto is located in the province of Santa Elena, Ecuador; with a territorial surface of $426 \mathrm{~km}^{2}$, great part of this territory is arid, but apt for the agriculture, nevertheless, it is limited by the lack of precipitations [13]; it consists of a population of 33,633 inhabitants according to the National Institute of Statistics and Censuses (INEC, 2010), from which large amounts of urban wastewater are generated, which, according to the article written by Braatz and Kandiah, are the liquid waste that is discharged from households, commercial premises and industrial plants, in individual disposal systems or in the pipes of municipal wastewater networks [4]. These waters are treated by oxidation lagoons, which consist of square or rectangular shallow excavations surrounded by earth slopes [14], such as the oxidation lagoons located in the municipality of Montañita, where the effluent is unloaded in the Cucaracha stream and later goes to the Grande river to finally reach the sea.

However, problems with the design of the oxidation lagoons have caused the discharge to contain large concentrations of pollutants due to the increase in wastewater. This limitation allows the search for new techniques of natural treatment of wastewater that saves operating expenses and allows to contribute to the reforestation of the area, using the system of green filters, trying to eliminate as many pollutants from the water current as comes from the lagoons of oxidation of the commune, according to the maximum permissible limits established in the Ecuadorian environmental standards. Therefore, the aim of this study is to design a pilot plant using the soil as a natural filter for the treatment of the wastewater discharge from oxidation ponds located in the Montañita commune through selecting and evaluating the site, calculating the design hydraulic load and the area necessary for system application.

\section{METHODOLOGY}

To carry out this work, a methodology was used that considers the development of experimental works both in situ and in the laboratory. This schedule of activities is detailed on a map (Fig. 1). 


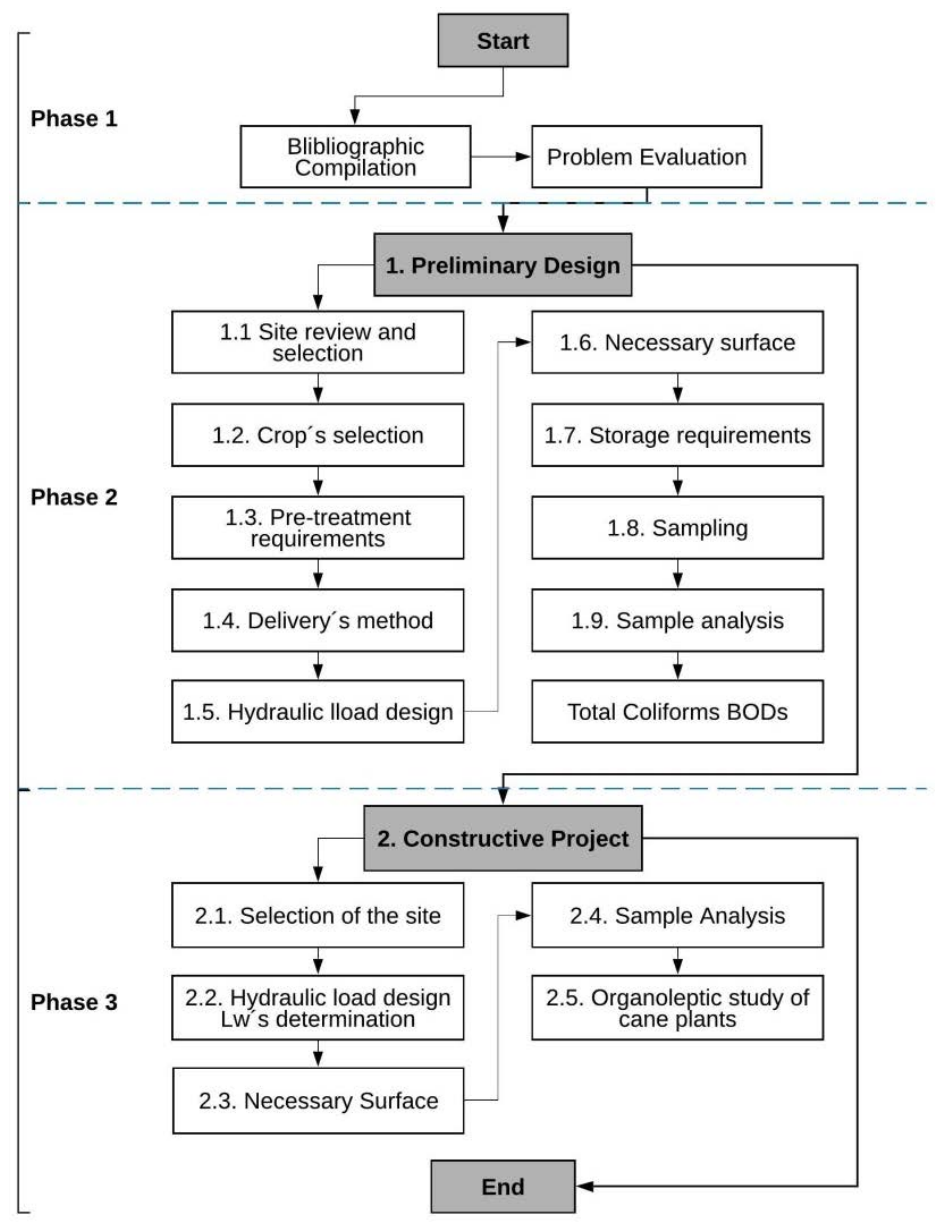

Figure 1: General project methodology.

\subsection{Phase I}

The work begins with the collection of bibliographic data that surround the problem through the research of books, scientific articles, magazines or related projects. Based on what has been collected, the problem is analyzed by studying all feasible techniques considering all the parameters in order to propose an optimal solution with their respective impacts.

\subsection{Phase II}

A sequence of processes described in the methodology of Fig. 1 was carried out for the design and analysis of a wastewater treatment plant, which complies with the scheme of Fig. 2.

2.2.1 Site evaluation and selection

The criteria used for the selection of the ideal site, in which the soil presents optimal conditions are [3]: 


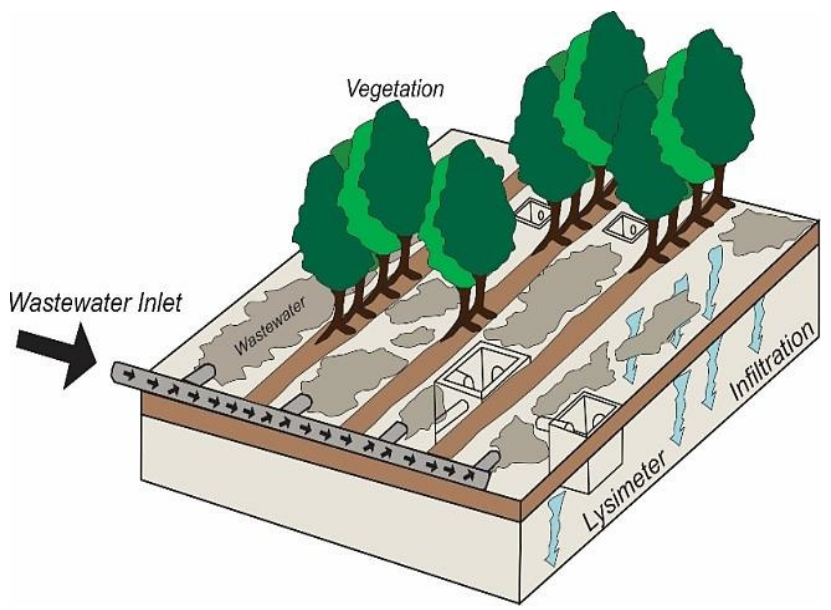

Figure 2: Scheme of wastewater treatment by green filters [15].

- The $\mathrm{pH}$ of the soil should be between 5.5 and 8.4 with conductivity lower than $4 \mathrm{mS} / \mathrm{cm}$.

- The permitted soil permeability range should be between 5 and $50 \mathrm{~mm} / \mathrm{h}$.

- Groundwater should be between 0.6 and $1.5 \mathrm{~m}$ deep.

These last two are preponderant factors for the election of the place.

\subsubsection{Crop selection}

The type of crop to be used was analyzed, based on the characteristics that a plant must have for the use of the green filter according to Álvarez [3]:

- High capacity of assimilation of nutrients and water consumption.

- High level of tolerance to soil moisture.

- Low sensitivity to wastewater components.

According to these guidelines, suitable plants are crops of forage, perennial, peat species.

\subsubsection{Water pre-treatment needs}

The need for water pre-treatment of the study sector was evaluated, considering public health issues, unfavorable effects and possible limitations of the distribution, cultivation or land system [3]. For this case, the water to be used comes from oxidation lagoons, which was treated through a primary treatment system, which basically consists of filters, grinding grids, grit chambers and degreasers.

\subsubsection{Water distribution method}

There are several methods of watering the wastewater in the plantation, such as [16]: sprinkling, surface irrigation, dripping and pulsing. The use of one or the other method will depend on the conditions in which it will be used in order to improve the efficiency of the application.

For this case, pulses were carried out since this method allows a better absorption of nitrogen by seeding [17], this occurs in cycles from a high to a low slope, so that the water penetrates both laterally and in depth to along the furrows. 


\subsubsection{Design hydraulic load}

It is the volume of wastewater applied per unit area of land for a given time [16]. It consists of several requirements described below:

- According to the requirements of crop water: an estimate is made to replace the water consumed by the evapotranspiration plus the water necessary for washing the soil. It is defined by the following expression

$$
R=\left(E T-P_{r}\right) x(1+L R)
$$

where:

$R$ : net water required by vegetation ( $\mathrm{mm} / \mathrm{month})$;

ET: Evapotranspiration ( $\mathrm{mm} / \mathrm{month})$;

$P_{r}$ : Precipitation respectively ( $\left.\mathrm{mm} / \mathrm{month}\right)$;

$L R$ : Water required for washing.

According to Álvarez, the water required for washing usually varies between 10 and $25 \%$ of the total water applied [3]. Since water is lost during irrigation as it is not applied uniformly over the work area, the hydraulic load is defined as

$$
\begin{gathered}
L w(I)=\frac{R}{E_{a}}, \\
L w(I)=\frac{\left(E T-P_{r}\right) x(1+L R)}{E_{a}},
\end{gathered}
$$

where:

$L w(I)$ : Hydraulic load based on vegetation water requirements ( $\mathrm{mm} / \mathrm{month})$; $E_{a}$ : Efficiency of application of the system.

In a pulsed irrigation system, the efficiency recorded in documents is $85 \%$ [18].

- Based on the hydraulic assimilation capacity of the soil-plant system: the expression that defines this is given by

$$
L w(I)=E T-P_{r}+P_{w}
$$

where:

$L w(P)$ : Hydraulic load based on hydraulic assimilation capacity soil-plant ( $\mathrm{mm} / \mathrm{month})$; $P_{w}$ : Speed of percolation ( $\left.\mathrm{mm} / \mathrm{month}\right)$.

In which, the percolation rate is based on the minimum permeability value under saturation conditions in the first $2.5 \mathrm{~m}$ of the stratigraphic column. For preliminary designs you can take a value between 2 and $6 \%$ of the minimum permeability of the soils present.

- Based on the assimilative capacity of the constituents: Each constituent of the wastewater can be a limiting factor of the hydraulic load depending on the concentration of this in the water, the assimilation capacity of the system and the environmental restrictions. For nitrogen, eqn (5) is used:

$$
L w(n)=\frac{C p\left(P_{r}-E T\right)+U x 100}{(1-f) C n-C p},
$$

where:

$L w(n)$ : Allowable hydraulic load based on the annual nitrogen load (mm/year);

$C p$ : Total concentration of nitrogen in the filtered water $(\mathrm{mg} / \mathrm{L})$;

$\mathrm{Cn}$ : Total concentration of nitrogen in the applied wastewater $(\mathrm{mg} / \mathrm{L})$;

$f$ : Fraction of total applied nitrogen, eliminated by de-nitrification;

$U$ : Nitrogen assimilation of the crop $(\mathrm{kg} / \mathrm{ha}$ year $)$. 
The values of $U$ and $f$ can be obtained in tables [5]. It can also be calculated by eqn (6), described by Ou et al. [19]:

$$
\operatorname{Lw}(c)=(M x 10) C
$$

where:

$L w(c)$ : Hydraulic load based on the assimilative capacity of the constituent (cm/year);

$M$ : Assimilative capacity of the constituent ( $\mathrm{kg} / \mathrm{ha}$ year);

$C$ : Concentration of the constituent in the wastewater.

The values of $M$ are found in several documents. In addition, it is known that forest plantations have a greater nitrogen assimilation capacity, with a maximum of $400 \mathrm{~kg} / \mathrm{ha}$ year [19].

After calculating the hydraulic loads, the lowest value is selected for the design. In case this value is the hydraulic load based on the assimilative capacity of the constituents, it is recommended to check the monthly values choosing the lowest for the design [3].

\subsubsection{Surface needed}

For the calculation, it has been considered: the cultivated area, the one required for the facilities, access zones, buffer and storage tanks. The expression used for the calculation of the necessary surface is summarized in eqn (7)

$$
A=\frac{Q \times 365 \times \Delta v_{s}}{10 \times L w},
$$

where:

A: Area of the field (ha);

$Q$ : Average residual water flow $\left(\mathrm{m}^{3} / \mathrm{d}\right)$;

$L w$ : Design hydraulic load;

$\Delta v_{s}$ : Net gains or losses of water stored due to precipitation, evaporation and leaks in the storage tank $\left(\mathrm{m}^{3} /\right.$ year$)$.

There is another equation to calculate the required surface

$$
A w=\frac{Q \times C}{12000 \mathrm{~g} / \mathrm{ha}},
$$

where:

$Q$ : Average daily treatment rate $\left(\mathrm{m}^{3}\right)$;

$C$ : Average $\mathrm{BOD}_{5}$ concentration in wastewater $(\mathrm{mg} / \mathrm{L})$.

The value of 12000 is a factor that is equivalent to the amount in grams of $\mathrm{BOD}_{5}$ assimilated in a hectare of land [3].

\subsubsection{Storage needs}

The analysis of the amount of wastewater is carried out. This is necessary when the residual water exceeds the hydraulic design load, which leads to two problems [3]:

- Production of anaerobic fermentations;

- Sludge formation as a result of the decanting of suspended solids.

Since the water comes from oxidation ponds, no extra storage facilities are required.

\subsubsection{Sampling}

For the study of the treated water, lysimeters are made at 30,60 and $90 \mathrm{~cm}$ deep at the end of the furrows where the water will flow. These lysimeters allow the collection of water samples. Its shape is $1 \mathrm{~m}$ cubic with holes on one side of $5 \mathrm{~cm}$ radius (Fig. 3). 


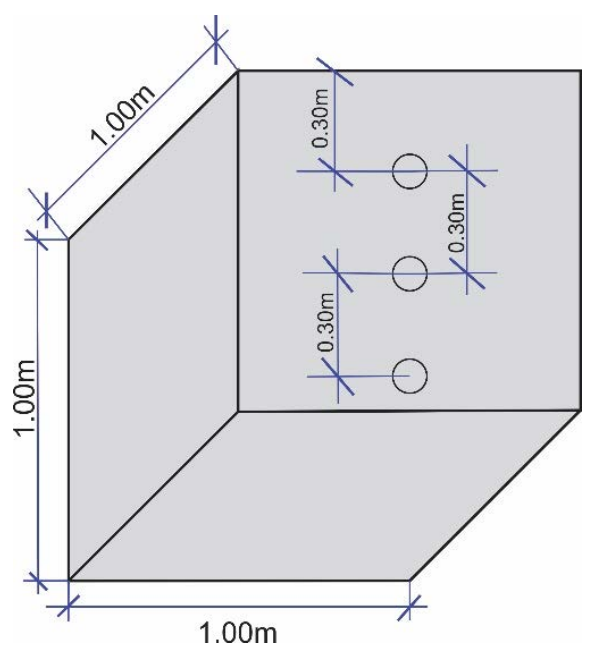

Figure 3: Scheme of a lysimeter.

\subsubsection{Analysis of samples}

Each sample taken by the lysimeter is analyzed for total coliforms and $\mathrm{BOD}_{5}$ for 3 weeks at a frequency of one week. The analysis of these parameters follows the normative of the Standard Methods for the Examination of Water and Wastewater in its 22nd edition [20]. These samples were analyzed in the Water Laboratory of the Escuela Superior Politécnica del Litoral (ESPOL).

\section{RESULTS}

\subsection{Place selection}

Based on the criteria described in the previous phase, the appropriate terrain for the implementation of the system, the site chosen for the pilot plant is adjacent to the location of the oxidation lagoons, as defined by the Manglaralto Drinking Water Management Board (JAAPMAN), as shown in Fig. 4.

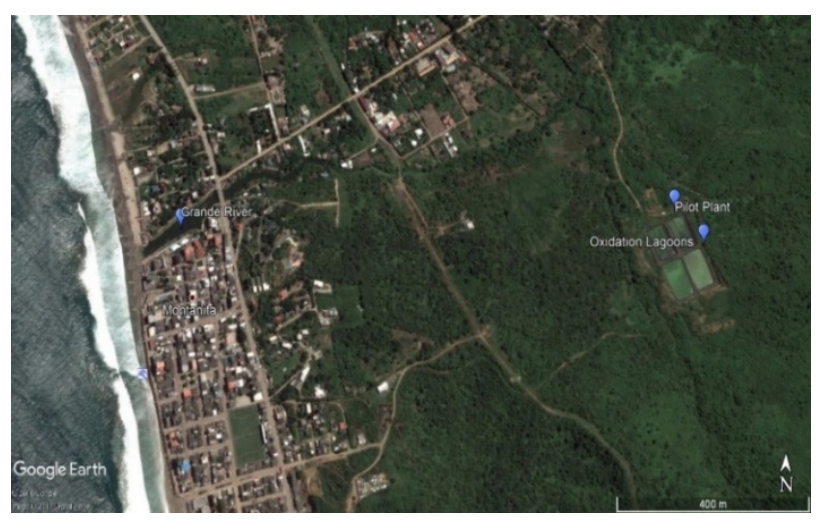

Figure 4: Pilot plant location map. (Source: Google Earth.) 
This land was subjected to several analyses for the determination of established parameters such as $\mathrm{pH}$ and conductivity. Among the properties of this terrain, it was found that at present edaphological levels consist of vertisol soils, whose predominant mineral is smectitic clay [16].

In addition, it was determined that the soil $\mathrm{pH}$ is 6.75 , the conductivity of $3.65 \mathrm{~m} \Omega / \mathrm{cm}$, is clay type, with a grain size of $400 \mu \mathrm{m}$.

\subsection{Crop selection}

The bamboo cane, besides being typical of the study sector, has been selected due to several benefits such as [17]:

- Provides protection to soils because their roots are large, they prevent soil erosion.

- It stores a large amount of water, in winter it can retain 25 liters of water, which it uses in summer due to scarcity.

- It captures around 110 tons of $\mathrm{CO}_{2}$ per hectare.

- Can be used to recharge the Manglaralto aquifer.

\subsection{Determination of the design hydraulic load}

In order to make a monthly evaluation of the rainfall in the place, data were taken from the meteorological station located in La Libertad, Santa Elena province due to its proximity to the study area (Table 1).

Table 1: Precipitation recorded at the La Libertad weather station [21].

\begin{tabular}{|l|c|}
\hline Month & Precipitations (mm/month) \\
\hline January & 65.6 \\
\hline February & 344.9 \\
\hline March & 211.5 \\
\hline April & 23.7 \\
\hline May & 3.6 \\
\hline June & 1.6 \\
\hline July & 1.5 \\
\hline August & 0.6 \\
\hline September & 0.2 \\
\hline October & 2.4 \\
\hline November & 0.3 \\
\hline December & 0 \\
\hline Annual & 655.9 \\
\hline
\end{tabular}

The potential evapotranspiration values were obtained from the project "Generation of geo-information for the management of the national territory scale 1:25,000", prepared by the National Secretariat of Planning and Development (SENPLADES) for the meteorological station of Salinas [18] (Table 2). It is taken as a source because of its proximity to the study area.

From the data obtained, the hydraulic load is calculated for the requirement of crop water. Table 3 shows the values of evapotranspiration $(E T)$, precipitation $(\mathrm{Pr})$ and net water required by the vegetation $(R)$. 
Table 2: Potential evapotranspiration calculated using the Thornthwaite formula, for the Salinas meteorological station [18].

\begin{tabular}{|l|c|}
\hline Month & Evapotranspiration (mm/month) \\
\hline January & 120.73 \\
\hline February & 119.46 \\
\hline March & 134.45 \\
\hline April & 120 \\
\hline May & 105.39 \\
\hline June & 89.19 \\
\hline July & 78.53 \\
\hline August & 71.87 \\
\hline September & 71.3 \\
\hline October & 81.11 \\
\hline November & 85.74 \\
\hline December & 104.18 \\
\hline Annual & 1181.95 \\
\hline
\end{tabular}

Table 3: Water requirement of the crop.

\begin{tabular}{|l|c|c|c|c|}
\hline Month & $\begin{array}{c}E T \\
(\mathrm{~mm} / \mathrm{month})\end{array}$ & $\begin{array}{c}P_{r} \\
(\mathrm{~mm} / \mathrm{month})\end{array}$ & $\begin{array}{c}R=\left(E T-P_{r}\right)(1+0.25) \\
(\mathrm{mm} / \mathrm{month})\end{array}$ & $\begin{array}{c}L w(I)=R / E_{a} \\
(\mathrm{~mm} / \mathrm{month})\end{array}$ \\
\hline January & 120.73 & 65.6 & 68.91 & 81.073 \\
\hline February & 119.46 & 344.9 & -281.8 & -331.52 \\
\hline March & 134.45 & 211.5 & -96.31 & -113.30 \\
\hline April & 120.00 & 23.7 & 120.37 & 141.61 \\
\hline May & 105.39 & 3.6 & 127.23 & 149.69 \\
\hline June & 89.19 & 1.6 & 109.48 & 128.80 \\
\hline July & 78.53 & 1.5 & 96.28 & 113.27 \\
\hline August & 71.87 & 0.6 & 89.08 & 104.80 \\
\hline September & 71.30 & 0.2 & 88.87 & 104.55 \\
\hline October & 81.11 & 2.4 & 98.38 & 115.75 \\
\hline November & 85.74 & 0.3 & 106.80 & 125.64 \\
\hline December & 104.18 & 0 & 130.22 & 153.20 \\
\hline Annual & \multicolumn{5}{|l}{} \\
\hline
\end{tabular}

The annual hydraulic load based on the resulting cultivation requirement is $773.60 \mathrm{~mm} /$ year.

The hydraulic load based on the assimilation of the soil-plant system depends on evapotranspiration $(E T)$, precipitation $\left(P_{r}\right)$ and soil permeability $\left(P_{w}\right)$. This data is obtained according to the type of soil, in this case, the soil is clay so it takes a value of $0.05 \mathrm{~cm} / \mathrm{h}$ or $360 \mathrm{~mm} /$ month [22] (Table 4).

The hydraulic load based on the assimilation capacity of the annual soil-plant system is $4,846.05 \mathrm{~mm} /$ year.

The hydraulic load based on the assimilative capacity of the constituents can take values of $8 \mathrm{mg} / \mathrm{L}$, with a nitrogen assimilation of $375 \mathrm{~kg} / \mathrm{ha}$ year in order to obtain a total nitrogen concentration of $20 \mathrm{mg} / \mathrm{L}$ [16] 
Table 4: Monthly assimilation capacity of the system.

\begin{tabular}{|l|c|c|c|c|}
\hline Month & $\begin{array}{c}E T \\
(\mathrm{~mm} / \mathrm{month})\end{array}$ & $\begin{array}{c}P_{r} \\
(\mathrm{~mm} / \mathrm{month})\end{array}$ & $\begin{array}{c}P_{w} \\
(\mathrm{~mm} / \mathrm{month})\end{array}$ & $\begin{array}{c}L w(P)=E T- \\
P_{r}+P_{w} \\
(\mathrm{~mm} / \mathrm{month})\end{array}$ \\
\hline January & 120.73 & 65.6 & 360 & 415.13 \\
\hline February & 119.46 & 344.9 & 360 & 134.56 \\
\hline March & 134.45 & 211.5 & 360 & 282.95 \\
\hline April & 120.00 & 23.7 & 360 & 456.30 \\
\hline May & 105.39 & 3.60 & 360 & 461.79 \\
\hline June & 89.19 & 1.60 & 360 & 447.59 \\
\hline July & 78.53 & 1.50 & 360 & 437.03 \\
\hline August & 71.87 & 0.60 & 360 & 431.27 \\
\hline September & 71.30 & 0.20 & 360 & 431.10 \\
\hline October & 81.11 & 2.4 & 360 & 438.71 \\
\hline November & 85.74 & 0.3 & 360 & 445.44 \\
\hline December & 104.18 & 0 & 360 & 464.18 \\
\hline Annual & \multicolumn{4}{|l}{} \\
\hline
\end{tabular}

Table 5: Calculated hydraulic loads.

\begin{tabular}{|c|c|}
\hline$L w$ & Hydraulic load \\
\hline$L w(I)$ & $773.60 \mathrm{~mm} /$ year \\
\hline$L w(\mathrm{P})$ & $4846.05 \mathrm{~mm} /$ year \\
\hline$L w(n)$ & $4745.91 \mathrm{~mm} /$ year \\
\hline
\end{tabular}

$$
\begin{gathered}
L w(n)=\frac{C p\left(P_{r}-E T\right)+U \times 100}{(1-f) C n-C p}, \\
L w(n)=\frac{8 \frac{\mathrm{mg}}{\mathrm{L}}\left(655.9 \frac{\mathrm{mm}}{\text { year }}-1181.95 \frac{\mathrm{mm}}{\text { year }}\right)+375 \frac{\mathrm{kg}}{\text { ha year }}\left(100 \frac{\mathrm{ha} \mathrm{mg} \mathrm{m}^{3} \mathrm{~mm}}{\mathrm{~kg} \mathrm{~m}^{2} \mathrm{~L} \mathrm{~m}}\right)}{(1-0.25) 20 \frac{\mathrm{mg}}{\mathrm{L}}-8 \frac{\mathrm{mg}}{\mathrm{L}}}, \\
L w(n)=4754.91 \frac{\mathrm{mm}}{\text { year }} .
\end{gathered}
$$

In summary, the values obtained from the hydraulic loads are detailed in Table 5.

Based on the above, the lowest value corresponds to the load based on the requirement of crop water with $773.60 \mathrm{~mm} /$ year.

\subsection{Necessary surface}

The area assigned based on the space that the bamboo cane requires as a plant for its growth was defined as the configuration shown in Fig. 5.

The arrow indicates the direction of the wastewater until its arrival in the lysimeter for sampling. The area is $39.88 \mathrm{~m}^{2}$ or 0.3988 ha. Based on this, the average daily flow is calculated from the equation

$$
A w=\frac{Q \times C}{12000 \mathrm{~g} / \mathrm{ha}} .
$$




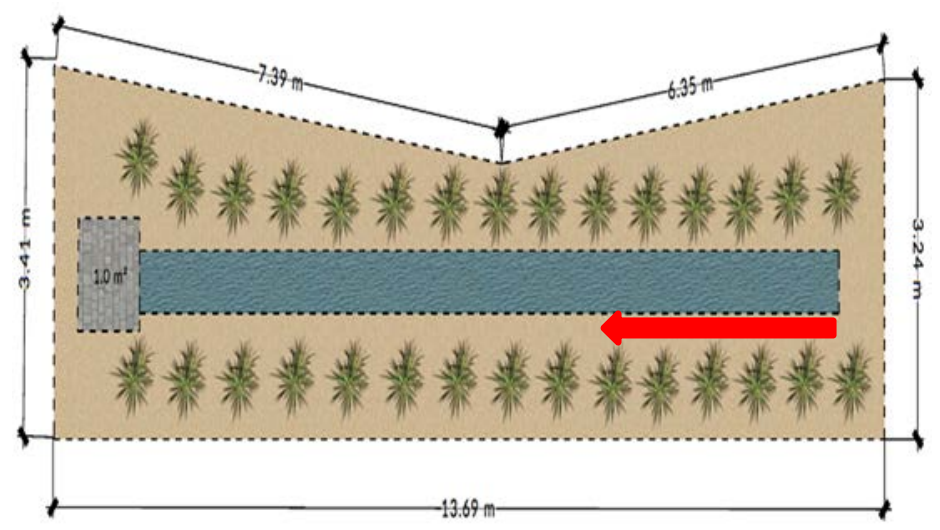

Figure 5: Configuration of the necessary surface.

For the use of this formula, an estimate was made of the average concentration of $\mathrm{BOD}_{5}$ in the wastewater, whose value is $109.51 \mathrm{mg} / \mathrm{L}$

$$
\begin{gathered}
0.3988 h a=\frac{Q \times 109.51 \mathrm{mg} / \mathrm{L}}{12000 \mathrm{~g} / \mathrm{ha}}, \\
Q=4.39 \mathrm{~m}^{3} / \text { day } .
\end{gathered}
$$

The values calculated in Table 6 are shown below.

Table 6: Summary of the calculated values.

\begin{tabular}{|l|c|}
\hline Hydraulic design load & $773.60 \mathrm{~mm} /$ year \\
\hline Necessary Surface & $39.88 \mathrm{~m}^{2}$ \\
\hline Average flow treated & $4.39 \mathrm{~m}^{3} /$ day \\
\hline
\end{tabular}

\subsection{Analysis of samples}

The volume of water of the samples taken by means of the lysimeter at depths of 30, 60 and $90 \mathrm{~cm}$, varies depending on the type of analysis to be carried out, as shown below.

\subsubsection{Total coliforms}

$120 \mathrm{~mL}$ of water were taken in sterile containers and then mobilized at $4^{\circ} \mathrm{C}$ to the ESPOL Water Laboratory. These analyzes were performed the same as the sample was taken to avoid a significant variation of microorganisms. Given that there are high concentrations of coliforms, a 1:100 dilution is made in order to quantify the colonies of bacteria in the colony counter, as indicated by the Standard Methods of Water and Wastewater [23].

The nomenclature used for the samples is recorded as follows:

- M30 indicates the sample taken with the lysimeter pipe at $30 \mathrm{~cm}$ depth.

- M60 indicates the sample taken with the lysimeter pipe at $60 \mathrm{~cm}$ depth.

- M90 indicates the sample taken with the lysimeter pipe at $90 \mathrm{~cm}$ depth.

The data obtained are specified in Table 7, adding that the effluent of the oxidation ponds has a value of $2890 \mathrm{CFU} / 100 \mathrm{~mL}$, which was obtained in the ESPOL Water Laboratory. At 
the same time, a value of $2400 \mathrm{NMP} / 100 \mathrm{~mL}$ was reported by the Laboratory Professionalism Laboratory Analysis Professionalism (PROTAL, acronym in Spanish).

Fig. 6 is a graph of coliform colonies as a function of depth in the different weeks of measurement.

Table 7: Water requirement of the crop.

\begin{tabular}{|c|c|c|}
\hline Sample & Dilution & Coliforms (UFC/100 Ml) \\
\hline \multicolumn{3}{|c|}{ Week 1 } \\
\hline M30 & $1: 100$ & 2350 \\
\hline M60 & $1: 100$ & 1960 \\
\hline M90 & $1: 100$ & 850 \\
\hline \multicolumn{3}{|c|}{ Week 2 } \\
\hline M30 & $1: 100$ & 2100 \\
\hline M60 & $1: 100$ & 1780 \\
\hline M90 & $1: 100$ & 630 \\
\hline \multicolumn{2}{|c|}{ Week 3 } \\
\hline M30 & $1: 100$ & 2060 \\
\hline M60 & $1: 100$ & 1650 \\
\hline M90 & $1: 100$ & 570 \\
\hline
\end{tabular}

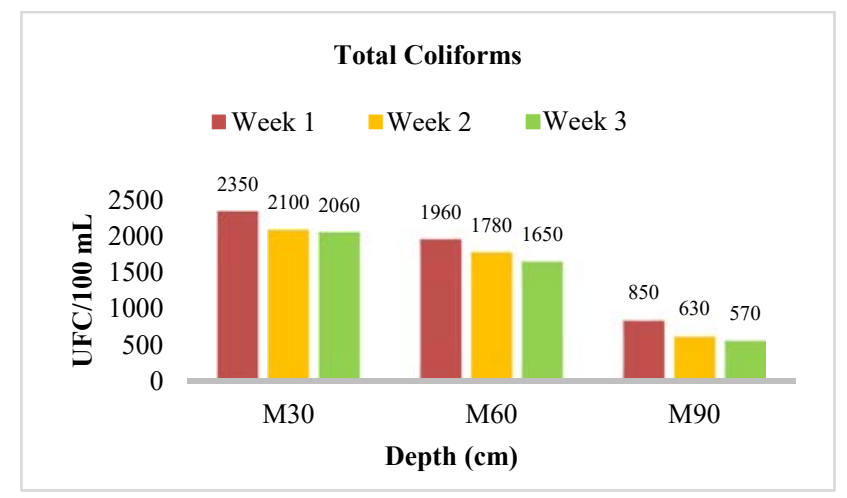

Figure 6: Total coliforms per week for samples M30, M60 and M90, expressed in $\mathrm{CFU} / 100 \mathrm{~mL}$.

Based on the graph, the decreasing behavior of the colonies is observed as the time increases. The regression model described by Cho et al. [24] was used to calculate the percentage of removal (Table 8).

The summer coefficients are selected due to the similarity between this and the work area. A model check is made with the data obtained by PROTAL, obtaining a relative error of $0.054 \%$, which validates the model used for the chosen conditions. Table 9 details the percentage of removal according to the week and the depth.

Fig 7 is a graph of the removal percentages obtained for each study point.

As the week progresses, the percentage of removal increases, as well as the depth, reaching $80 \%$ removal at the third week at $90 \mathrm{~cm}$ below ground level. 
Table 8: Coefficients for regression model that allows converting concentrations of CFU to NMP [24]. (Modified by the author.)

\begin{tabular}{|l|l|c|c|c|c|}
\hline \multicolumn{2}{|c|}{} & Spring & Summer & Autumn & Winter \\
\hline \multirow{4}{*}{ Coliforms } & ln a & 1.27 & -0.51 & -1.23 & 2.09 \\
\cline { 2 - 6 } & (std. error) & 0.18 & 0.33 & 0.47 & 0.31 \\
\cline { 2 - 6 } & b & 0.80 & 1.04 & 1.36 & 0.36 \\
\cline { 2 - 6 } & (std. error) & 0.04 & 0.05 & 0.09 & 0.07 \\
\hline
\end{tabular}

Table 9: Percentage of removal of total coliforms calculated with samples M30, M60 and M90 in the three weeks of study.

\begin{tabular}{|c|c|c|c|}
\hline Sample & Week 1 & Week 2 & Week 3 \\
\hline M30 & $19 \%$ & $27 \%$ & $29 \%$ \\
\hline M60 & $32 \%$ & $38 \%$ & $43 \%$ \\
\hline M90 & $71 \%$ & $78 \%$ & $80 \%$ \\
\hline
\end{tabular}

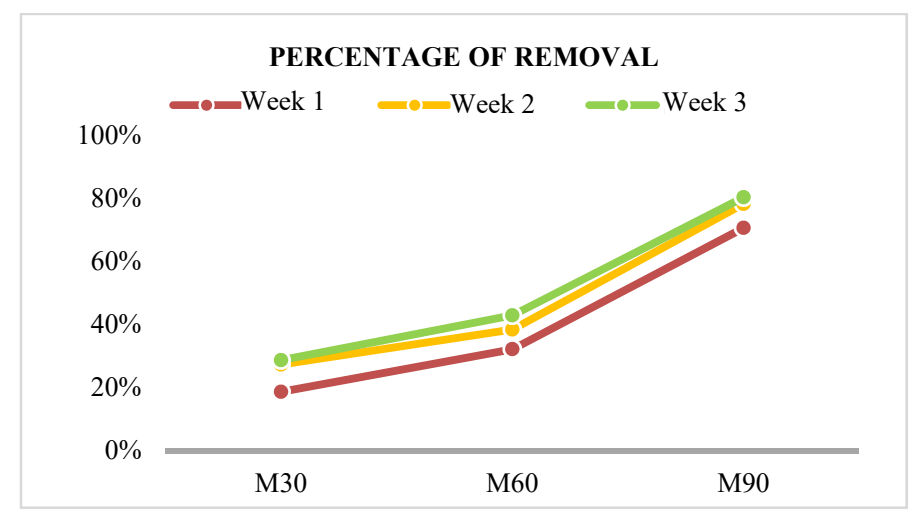

Figure 7: Percentage of removal of total coliforms per week, for samples M30, M60 and M90.

\subsection{2 $\mathrm{BOD}_{5}$}

The analysis is carried out under the guidelines proposed by the "Standard Methods for the Examination of Water and Wastewater", taking water samples of approximately $500 \mathrm{ml}$ per sample, in amber bottles. From this, the data described in Table 10 were obtained and displayed in Fig. 8.

The behavior of $\mathrm{BOD}_{5}$ follows the same decrease trend as total coliforms. As time and depth increase, the $\mathrm{BOD}_{5}$ values decrease. To calculate the percentage of removal, the $\mathrm{BOD}_{5}$ calculated in the oxidation pond was used as data, which was $109.51 \mathrm{mg} / \mathrm{L}$. The values are shown below in the Table 11 .

Fig. 9 is a graph of the removal percentages obtained for each study point.

In both analyzes, high percentages of removal were obtained, reaching up to $80 \%$ fulfilling the description by Álvarez [3] in the publication "Filtros Verdes. An ecological purification system", where it is exposed that this type of systems can achieve a purification performance 
Table 10: $\mathrm{BOD}_{5}$ values recorded the first week.

\begin{tabular}{|c|c|}
\hline Sample & BOD $_{5}(\mathrm{mg} / \mathrm{L})$ \\
\hline \multicolumn{3}{|c|}{ Week 1 } \\
\hline M30 & 106.91 \\
\hline M60 & 101.51 \\
\hline M90 & 96.41 \\
\hline \multicolumn{2}{|c|}{ Week 2 } \\
\hline M30 & 96.37 \\
\hline M60 & 87.07 \\
\hline M90 & 65.47 \\
\hline \multicolumn{2}{|c|}{ Week 3 } \\
\hline M30 & 83.68 \\
\hline M60 & 68.68 \\
\hline M90 & 22.48 \\
\hline
\end{tabular}

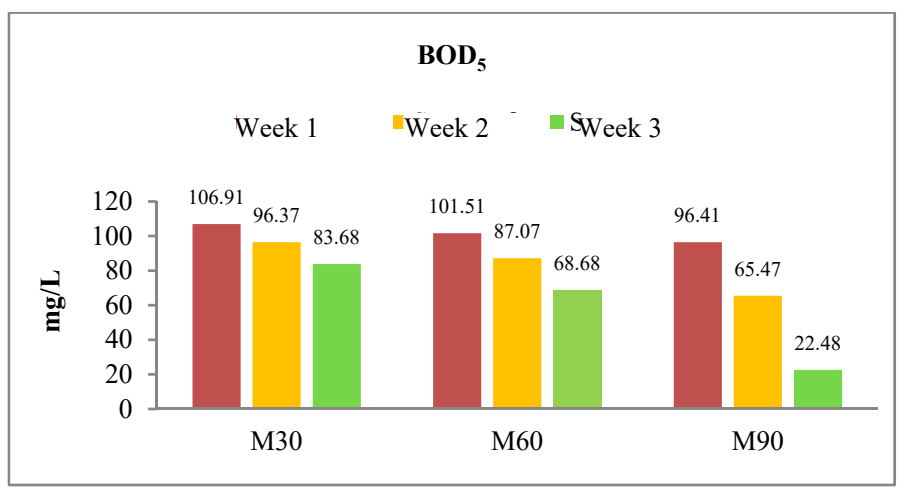

Figure 8: Total $\mathrm{BOD}_{5}$ per week for samples M30, M60 and M90, expressed in mg/L.

Table 11: Percentage of removal of $\mathrm{BOD}_{5}$ calculated with samples M30, M60 and M90 in the three weeks of study.

\begin{tabular}{|c|c|c|c|}
\hline Sample & Week 1 & Week 2 & Week 3 \\
\hline M30 & $2 \%$ & $12 \%$ & $24 \%$ \\
\hline M60 & $7 \%$ & $20 \%$ & $37 \%$ \\
\hline M90 & $12 \%$ & $40 \%$ & $79 \%$ \\
\hline
\end{tabular}

of up to $98 \%$. In addition, according to CONAGUA [16], in the "Manual of Drinking Water, Sewerage and Sanitation", it is commented that green filters can reach $85 \%$ in the removal of organic matter present in wastewater.

Regarding the Environmental Quality Standard and Discharge of Effluents: Water Resource, the limit allowed for agricultural use is $1000 \mathrm{NMP} / 100 \mathrm{~mL}$ in total coliforms and $100 \mathrm{mg} / \mathrm{L}$ of $\mathrm{BOD}_{5}$ [25]. The pilot plant of green filters obtained values below the limit after the test time, complying with the standards established in the country. 


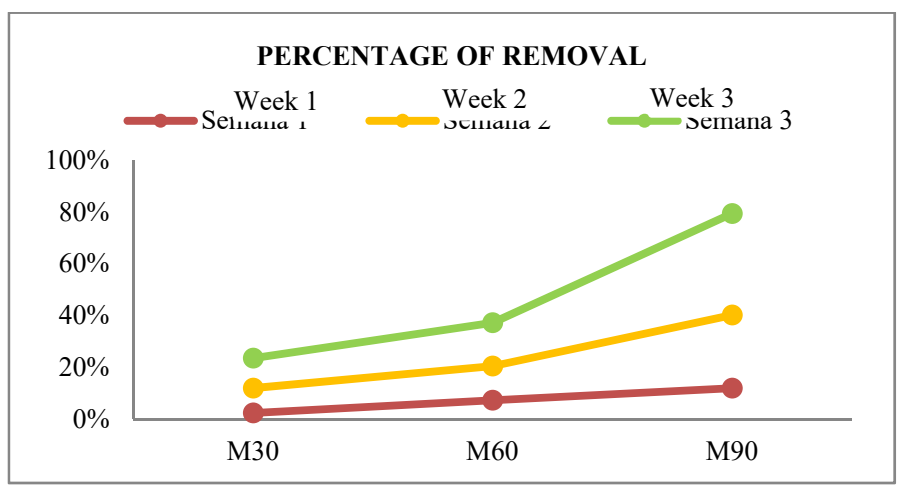

Figure 9: Percentage of $\mathrm{BOD}_{5}$ removal per week for M30, M60 and M90 samples.

\section{CONCLUSIONS}

From the results obtained in the experiments carried out by the pilot plant, it is verified that the system is feasible, since it reduced the proposed parameters such as $\mathrm{BOD}_{5}$ and total coliforms from the oxidation lagoons up to $80 \%$ at depths of up to $90 \mathrm{~cm}$, complying with the Ecuadorian environmental quality regulations for both cases, contributing to the reuse of wastewater for reforestation of the arid study area with little access to fresh water.

The type of soil where the pilot plant was built is silt-clayey, with the necessary characteristics that allow a slow and effective filtration for the removal of contaminants. Based on the type of soil and the study area, it was determined that bamboo cane, being an endemic species of the country and typical of the place, is the one indicated for the treatment. This type of soil and crop, to perform the treatment of wastewater from the daily flow of the oxidation lagoons, needs a minimum area of 41.39 hectares.

Based on the analysis of total coliforms, it was found that the lowest percentage of total coliform removal was $19 \%$ for sample M30 in week 1, with a total of $2350 \mathrm{NMP} / 100 \mathrm{~mL}$, and a maximum percentage of $80 \%$ for the M90 sample in week 3, with a total of $570 \mathrm{NMP} / 100 \mathrm{~mL}$.

For $\mathrm{BOD}_{5}$ the lowest removal percentage corresponded to $2 \%$ for sample M30 in week 1 , with a total of $106.91 \mathrm{mg} / \mathrm{L}$ and a maximum percentage of $79 \%$ for sample M90 in week 3, with a total of $22.48 \mathrm{mg} / \mathrm{L}$.

With the application of green filters, the reliability of the implemented system and its excellent response to different depths were demonstrated, which allows the establishment of a larger scale planning.

\section{RECOMMENDATIONS}

It is recommended to implement this project in several arid and semi-arid zones of the country to reactivate the soil and improve the living conditions of the villagers.

Perform a monitoring by means of the physical-chemical-biological analysis of the soil that is being used as a green filter, to determine the concentration of pathogens and contaminants, which allow evaluating its temporal efficiency.

\section{REFERENCES}

[1] Deurer, M., Aslam, T., Ralle, S., Green, R. \& Clothier, B.E. Soils as buffers and filters. Research Gate, 2019. 
[2] Kadam, A., Nemade, P., Oza, G. \& Shankar, H., Treatment of municipal wastewater using laterite-based constructed soil filter. Ecological Engineering, pp. 1051-1061, 2009.

[3] Álvarez, F., Filtros verdes. Un sistema de depuración ecológico. Ingeniería Hidráulica y Ambiental, 23(1), pp. 25-29, 2002. (In Spanish.)

[4] Braatz, S. \& Kandiah, A., Utilización de aguas residuales urbanas para el riego de árboles y bosques. Unasylva, 1(185), pp. 11-22, 2004. (In Spanish.)

[5] Metcalf, E., Ingeniería de Aguas Residuales. Tratamiento, Vertido y Reutilización. McGraw-Hill, 1995. DOI: 10.1036/0070418780. (In Spanish.)

[6] Noboa, M.E., Comparación del efecto de riego con aguas residuales provenientes de las lagunas de oxidación de Santa Elena, sobre 4 especies forestales en etapa vivero, 2010. (In Spanish.)

[7] Chen, X., Luo, A.C., Sato, K., Wakatsuki, T. \& Masunaga, T., An introduction of a multi-soil-layering system: A novel green technology for wastewater treatment in rural areas. Water and Environment Journal, 23(4), pp. 255-262, 2009.

[8] Moscoso, J., Casos prácticos de uso de aguas residuales. CEPIS (Centro Panamericano de Ingeniería Sanitaria y Ciencias del Ambiente), OPAS (Organización Panamericana de la Salud), OMS (Organización Mundial de la Salud), 2002. www.cepis.org.pe. (In Spanish.)

[9] Candela, L., Fabregat, S., Josa, A., Suriol, J., Vigués, N. \& Mas, J., Assessment of soil and groundwater impacts by treated urban wastewater reuse: A case study Application in a golf course (Girona, Spain). Science of the Total Environment, 374(1), pp. 26-35, 2007.

[10] Ayers, R.S. \& Westcot, D.W., Water quality for agriculture. FAO Irrigation and Drainage Paper, vol. 29. FAO: Rome, 174 pp., 1994.

[11] Levine, A. \& Assano, T., Recovering sustainable water from wastewater. Water Sci. Technol., 201, 2004.

[12] United States Environmental Protection Agency, Method 1604: Total Coliforms and Escherichia Coli in Water by Membrane Filtration using a Simultaneous Detection Technique (MI Medium). US Environmental Protection Agency: Washington, DC, 2002.

[13] Borbor, A. \& Vera, J., Estudio para la optimización de la distribución de agua para consumo humano, por parte de la Junta Regional de Manglaralto, Santa Elena, Ecuador, 2014. (In Spanish.)

[14] Pérez, A., Tratamiento de aguas residuales en pequeñas comunidades, pp. 46-65, 2009. http://tesis.uson.mx/digital/tesis/docs/19117/capitulo4.pdf. (In Spanish.)

[15] Instituto Tecnológico de Canarias, Sobre los Sistemas de Depuración Natural (SDN's), 15 Apr. 2019. http://depuranatura.blogspot.com/2011/05/filtros-verdes-la-tecnologiade.html. (In Spanish.)

[16] CONAGUA, Manual de Agua Potable, Alcantarillado y Saneamiento Operación y Mantenimiento de Plantas de Tratamiento de Aguas Residuales Municipales: Lagunas Aireadas, 2015. http://aneas.com.mx/wp-content/uploads/2016/04/SGAPDS-1-15Libro30.pdf. (In Spanish.)

[17] El Mercurio., Riego por pulsos, una alternativa para aumentar los rendimientos del maíz, 2013. www.elmercurio.com/Campo/Noticias/Noticias/2013/06/11/Riego-porpulsos-una-alternativa-para-aumentar-los-rendimientos-del-maiz.aspx. Accessed on: 27 Jul. 2018. (In Spanish.)

[18] SENPLADES, Generacion De Geoinformacion Para La Gestion Del Territorio A Nivel Nacional Escala 1:25.000, 2011. (In Spanish.) 
[19] Ou, Z. et al., A production-scale ecological engineering forest system for the treatment and reutilization of municipal wastewater in the Inner Mongolia, China. Ecological Engineering, 9, pp. 71-88, 1997.

[20] Rice, E.W. \& Bridgewater, L., Standard Methods for the Examination of Water and Wastewater, 22nd ed., American Public Health Association: Washington, DC, 2012.

[21] INOCAR (Instituto Oceanográfico de la Armada), Precipitación por estación, 2017. www.inocar.mil.ec/web/index.php/precipitacion-por-estacion. Accessed on: $27 \mathrm{Jul}$. 2018. (In Spanish.)

[22] FAO, Permeabilidad del suelo. www.fao.org/fishery/static/FAO_Training/ FAO_Training/General/x6706s/x6706s09.htm. Accessed on: 27 Jul. 2018. (In Spanish.)

[23] Rice, E.W. \& Bridgewater, L., "Microbiological examination": Membrane filter technique for members of the coliform group. Standard Methods for the Examination of Water and Wastewater, ed. E. Rice, American Public Health Association: Washington, DC, 2012.

[24] Cho, K.H. et al., Evaluation of the relationship between two different methods for enumeration fecal indicator bacteria: Colony-forming unit and most probable number. Journal of Environmental Sciences, 22(6), pp. 846-850, 2010. DOI: 10.1016/S1001-0742(09)60187-X.

[25] Ministerio del Ambiente, Norma De Calidad Ambiental Y De Descarga De Efluentes: Recurso Agua, pp. 1-37, 2014. 